Krzysztof Skorulski*

ORCID: 0000-0002-2507-4781

Innsbruck

\title{
Przez dramat do dialogu. Rola „Słowa” w dochodzeniu do dialogu według Ferdynanda Ebnera
}

Być może warto zaryzykować postawienie tezy, że realistycznie i praktycznie podchodzący do sprawy filozof czy - ogólniej - teoretyk dialogu więcej miejsca poświęca warunkom dojścia do dialogu niż samemu dialogowi. Postawę taką zauważamy choćby u tego, który jako pierwszy przychodzi na myśl jako przedstawiciel tego typu myślenia w Polsce - u Józefa Tischnera. O dialogu czytamy u niego stosunkowo mało, dużo więcej o dramacie, złu itd. Moim zdaniem nie jest to przypadek, lecz konsekwencja widzenia dialogu jako sytuacji docelowej, jako punku dojścia pewnej - niełatwej - drogi. Śledząc obecne w życiu społecznym i politycznym użycie słowa „dialog”, trudno nie zauważyć z jednej strony podejścia „naiwnego” (prób prowadzenia dialogu przy braku warunków do jego zaistnienia, nazywania dialogiem sytuacji mu obcych, wręcz każdej komunikacji), z drugiej zaś ,,abstrakcyjnego”, oderwanego od konkretnych sytuacji (krytyki i odrzucania wszystkiego, co nie odpowiada wzniosłemu rozumieniu dialogu), przy czym oba podejścia zniewalają w konkretnych sytuacjach międzyludzkich

* Dr Krzysztof Skorulski jest sekretarzem generalnym Międzynarodowego Towarzystwa Ebnerowskiego (Internationale Ferdinand Ebner Gesellschaft) w Innsbrucku i kieruje w nim Sekcją Badań Naukowych. Adres: Internationale Ferdinand Ebner Gesellschaft, Brenner-Archiv, 6020 Innsbruck, Josef-Hirn-Str. 5/10, Austria; e-mail: krzysztof.skorulski@ebner-gesellschaft.org. 
(dlatego Ferdinand Ebner pisze o „łańcuchach abstrakcji”"). Do tego dochodzi instrumentalizacja dialogu dla osiągnięcia własnych, przeważnie „niedialogicznych" celów. Są to zjawiska niszczące i dyskredytujące sam dialog, i to zarówno „dialog” jako pojęcie, jak i opisywaną przez nie rzeczywistość, dyskwalifikujące coś, co nie tylko określa człowieka w jego istocie, lecz czego człowiek pilnie potrzebuje. Należałoby więc podjąć wszelki możliwy wysiłek, by obu tych nastawień uniknąć.

Przytoczę tu, pochodzący z klasycznej książki Paula Watzlawicka (austriacko-amerykański teoretyk komunikacji), przykład stosunkowo niegroźny, czy wręcz humorystyczny, który pokaże nam, na czym polega problem. Otóż: mam przed sobą osiem godzin lotu samolotem i siada obok mnie gaduła. Wszystkie miejsca są zajęte. Powiedzmy, że znam ten rodzaj człowieka i wiem, czego ode mnie oczekuje: gaduła nie popuści, będzie męczył i gadał albo wypytywał, przy czym każda moja odpowiedź wywoła kilka dalszych pytań. Nie o dialog jednak mu chodzi - chce użyć mnie jedynie jako rodzaju odbiornika, by wygadać się, lub zwierciadła, by oglądać samego siebie. Nikt chyba nie lubi odgrywać takiej roli. Ale jestem dialogicznie nastawiony i chcę walczyć o dialog. Zaczyna się więc „dramat” w sensie Tischnera.Watzlawick wymienia cztery możliwości. Mogę podjąć wyzwanie i starać się doprowadzić do prawdziwego dialogu. Mogę odmówić, narażając się na godziny obrażonego milczenia. Mogę udawać nieobecność, na przykład że śpię albo że nie rozumiem języka, w którym mówi. Mogę wreszcie dawać nonsensowne odpowiedzi, a dokładniej stosować falsyfikację (disconfirmation) wypowiedzi własnych lub partnera ${ }^{2}$. Sens poszczególnych zachowań omówię później. Tu postawię jedynie zasadnicze pytanie: jakie zachowanie odpowiada mojej dialogicznej postawie i ewentualnie doprowadzi mnie do faktycznego dialogu?

Stwierdziłem, że wraz z wejściem w kontakt zaczyna się „dramat” w sensie Tischnera. Dramat w jego rozumieniu polega bowiem w gruncie rzeczy na tym, czy dojdzie się do sytuacji dialogu, czy też nie. Zauważmy też, że w jego rozważaniach zło powstrzymuje właśnie przed wejściem w dialog, zamyka, izoluje. Zło jest według niego „,antygrawitacją”. Zło odpycha wszystko i wszystkich ${ }^{3}$.

${ }^{1}$ Ferdinand Ebner, Schriften, wyd. Franz Seyr, t. 2 (München: Kösel, 1963), 1031.

2 Paul Watzlawick, Janet Beavin Bavelas, Don D. Jackson, Pragmatics of Human Communication: A Study of Interactional Patterns, Pathologies, and Paradoxes (New York: Norton, 1967), $74 \mathrm{n}$.

3 Józef Tischner, Spór o istnienie człowieka (Kraków: Znak, 1999), 225. 
Także Ebner widzi dialog (określając go jednak przez „stosunek Ja do Ty”) jako właściwą i docelową sytuację człowieka jako „realności duchowej”. Pisze on: „Człowiek od samych podstaw nastawiony jest na relację do czegoś duchowego poza nim, przez co i w czym on sam istnieje"4. Człowiek został więc „nastawiony” na relację, ale w konkretnej sytuacji egzystencjalnej musi zaczynać od „samotności Ja”, by przezwyciężyć tę samotność i dojść do dialogu. W sensie teologicznym Ebner widzi tę początkową sytuację jako sytuację grzechu ${ }^{5}$, podczas gdy dialog jest zbawieniem, bo nasze zbawienie leży przecież w relacji z Bogiem.

Zwróćmy uwagę, że temat ten podejmowany był u wielu myślicieli zajmujących się człowiekiem, szczególnie u takich, którzy uwzględniali relację jako przynależącą do istoty człowieka czy też, inaczej mówiąc, do jego sposobu istnienia: ta dynamika walki o przejście do dialogu, choć rozmaicie ujmowana pojęciowo, obecna jest na przykład u Hanny Arendt (od przemocy przez nieposłuszeństwo obywatelskie do prawdziwej wolności) czy Emmanuela Levinasa (z głębi okropności obozów koncentracyjnych poprzez „nie zabijesz mnie" do sytuacji dialogicznej). Występuje także w tekstach spoza filozofii sensu stricto, na przykład w pedagogice Paulo Freirego (w jego Pedagogii uciśnionych chodzi o przejście od sytuacji ucisku do wolności przez „budzenie świadomości”, nadanie uciśnionym ich własnego słowa), czy w psychologii i teorii komunikacji wspomnianego Paula Watzlawicka (,nie można nie komunikować się", czyli komunikacja jest zawsze, ale nie zawsze „zdrowa” czy „partnerska” - inaczej mówiąc: dialogiczna).

Lektura każdego z wymienionych myślicieli dostarcza interesujących impulsów odnośnie do dróg dochodzenia do dialogu, którym chcę poświęcić uwagę w tym artykule. W pewnym sensie chciałbym wraz z Tischnerem wystąpić nawet „przeciw dialogowi”, a za „dramatem”- w tym sensie, że w codzienności żyjemy nie tyle w sytuacji dialogu, ile walki o dialog, czyli w sytuacji dramatu. Dopuszczalna objętość artykułu zmusza mnie jednak do ograniczenia pól poszukiwania. Skoncentruję się więc, sięgając co prawda do inspiracji Tischnerowskich, na analizie sformułowań mniej znanego, choć w sposób pośredni bardzo wpływowego Ferdynanda Ebnera?

${ }^{4}$ Ferdynand Ebner, Stowo i realności duchowe. Fragmenty pneumatologiczne, thum. Krzysztof Skorulski (Chojnice: Oficyna Wydawnicza Fundacji Fuhrmanna, 2016), 23.

5 Tamże, 141; por. tamże, 31.

${ }^{6}$ Por. Watzlawick, Bavelas, Jackson, Pragmatics, 53.

7 Odnośnie do wpływu Ferdynanda Ebnera na filozofię i teologię katolicką - por. Krzysztof Skorulski, „Ferdinand Ebner i miejsce filozofii dialogu w myśli katolickiej XX wieku”, 
Ebner widzi rzeczywistość ludzką w jej charakterze duchowym (w odróżnieniu od biologicznego) na sposób, który można by nazwać „komunikacją duchową". Mówi o „życiu duchowym” jako o stosunku czy też relacji Ja do Ty, dokonującej się, a przynajmniej postrzegalnej obiektywnie, w słowie i subiektywnie w miłości. „Słowo jako «nośnik obiektywny» relacji między Ja i Ty i miłość jako jej «nośnik subiektywny» pozostają w bliskim związku" . Znaczy to, że dostrzec drugiego jako realność duchową mogę wtedy, gdy słyszę „z zewnątrz” jego słowo i gdy odczuwam „wewnątrz” „miłość” do niego (jednak nie w sensie sentymentalnym, lecz raczej w sensie Agape).

Jak więc stwierdzić, czego brakuje, aby zaistniał dialog? Na kanwie przedstawionej wizji Ebnera udaje się to dosyć łatwo i schematycznie. Ja komunikuje się z Ty poprzez słowo oraz milość. Jeśli nie ma dialogu, to któregoś z tych elementów po prostu brakuje. Wróćmy do przykładu z książki Watzlawicka i przeanalizujmy go według tego schematu. Pierwsza możliwość reakcji na gadułę, to znaczy „podjąć wyzwanie”, oznacza wiarę, że dzięki mojemu słowu zdołam „obudzić” Ty w drugim. Druga, „odmówić rozmowy", prowadzi zasadniczo w tym samym kierunku, jeśli jej celem jest zwrócenie uwagi, że gadulstwo nie jest dialogiem. Trzecia, udawanie nieobecności, ukrywa moje Ja - pokazuję, że nie jestem partnerem do takiej rozmowy, a czynię to, chcąc - że tak powiem - chronić moje Ja przed jego „odczłowieczeniem”. Czwarta możliwość - „schizofrenia” - jest „ukrywaniem” mojego Ja w sytuacji, gdy nie mogę udać, że mnie „fizycznie” dla drugiego nie ma i być nieobecnym przynajmniej „duchowo". Ta możliwość sugeruje też ewentualnie „bezwartościowość”, a więc negację słowa.

Jako że forma artykułu nie pozwala rozważyć wszystkich momentów „komunikacji duchowej”, skupię się tu na słowie. Ebnerowi chodzi o Słowo nie w sensie jednostki gramatycznej, lecz „wypowiedzi”, to znaczy użyte tak jak w zdaniu „kieruję do Ciebie słowo”. Podkreśla on przy tym rolę aktualności słowa, to znaczy jego rolę raczej w konkretnej sytuacji dialogu niż $\mathrm{w}$ ramach systemu językowego. W dialogu słowo ma konkretne, aktualne konotacje, rozumiane często jedynie przez partnerów rozmowy. Przeanalizujmy tu aspekty słowa, które mają znaczenie dla powstania dialogu, umożliwiając go lub uniemożliwiając.

Paedagogia Christiana 1 (2011): 49-68. Gdy zaś chodzi o jego zakorzenienie w życiu kulturalnym ówczesnej Austrii - por. Walter Methlagl, „Konflikt aspektów. Ferdinanda Ebnera myślenie w odniesieniach", Paedagogia Christiana 1 (2015): 41-62.

${ }^{8}$ Ebner, Stowo, 58. 


\title{
1. Osobowa i rzeczowa aktualność słowa
}

Po pierwsze, słowo ma zawsze wymiar zarówno rzeczowy, jak i osobowy. Można więc mówić także o jego aktualności osobowej i rzeczowej. Ebner notuje 5 lipca 1920 roku:

\begin{abstract}
Aktualność rzeczowa budzi zainteresowanie obiektywne (i odwrotnie, zainteresowanie to zbliża się do niej, do słowa w jego odniesieniu rzeczowym, przez co właśnie słowo w sensie rzeczowym staje się aktualne). Aktualność osobowa budzi w człowieku zainteresowanie subiektywne, jego zainteresowanie samym sobą, tzn. życiem duchowym w nim samym?
\end{abstract}

Słowo ma więc jednocześnie dwie funkcje do wypełnienia, winno mianowicie niejako „łączyć” Ja i Ty, budować relację między nimi, być nośnikiem tejże, a jednocześnie ma zapewniać dostęp do rzeczywistości zewnętrznej. Dwie osoby rozmawiają bowiem zawsze o czymś. Można też mówić o osobowym i rzeczowym sensie słowa: sensem osobowym jest budowa relacji - słowo ma sens, jeśli ją buduje, gdy zapewnia dostęp do Ty; podczas gdy sens rzeczowy, niejako umocowując tę relację w rzeczywistości, zapewnia dostęp do rzeczy. Można odnieść wrażenie, że duża część ludzi zauważa jedynie jeden z tych dwóch aspektów: albo - jak generalnie w naukach ścisłych - chodzi im o ,prawdę materialną" bez uwzględnienia relacji, jej znaczenia dla konkretnych ludzi, albo - jak u niektórych radykalnych dialogików - chodzi o mniemaną bezgraniczną otwartość na drugiego bez uwzględnienia zewnętrznej sytuacji, niejako oddanie się mu do dyspozycji bez patrzenia na to, co z nami zrobi. Dopiero gdy słowo spełnia kryterium aktualności, i to zarówno osobowej, jak i rzeczowej, jest ono słowem właściwym (niem. das rechte Wort) ${ }^{10}$. Co ciekawe, u Ebnera rozróżnienie to zajmuje niewiele miejsca, zyskując na znaczeniu w późniejszych jego pismach. Być może, zafascynowany odkryciem wymiaru osobowego słowa, dopiero później dostrzegł całą dialogiczną doniosłość - oczywistego przecież - wymiaru rzeczowego. Ta sama problematyka pobrzmiewa jednak także u Tischnera, zwłaszcza - inaczej rozpracowana - w opisie współzależności między sceną dramatu a występującymi na niej osobami.

\footnotetext{
${ }^{9}$ Ebner, Schriften, t. 2, 261.

${ }^{10}$ Ebner, Stowo, 116.
} 


\section{Slowo generatywne i maieutyczne}

Wróćmy jeszcze raz do wiary w moc słowa odnośnie do doprowadzania do dialogu w konkretnej sytuacji: Ebner mówi w tym kontekście o słowie generatywnym i maieutycznym. Odnosząc się konkretnie do słowa Chrystusa w Ewangelii, podkreśla że istnieje: „osobowa (osobista) aktualność słowa Chrystusa, ten moment w tym słowie, który w odróżnieniu od słowa jakiegoś światowego i życiowego mędrca czy poety ma dla życia duchowego w człowieku znaczenie nie tylko «maieutyczne», lecz w swej istocie «generatywne»"11. Tę właśnie generatywną moc słowa należy jednak dostrzec, podjąć $\mathrm{w}$ wierze, której słowo się domaga „W swym domaganiu się wiary jest to «najbardziej osobiste» słowo, które zostało wypowiedziane na tym świecie" "12. Przejście na poziom osobisty, ten, na którym naprawdę „moje Ja wchodzi w grę", gdzie nie ukrywam się za jakimś gadulstwem czy kłamstwem, równoznaczne jest z zaistnieniem dialogu.

Jednak moim zdaniem „moc generatywna” ma swoją specyfikę, która wymaga dodatkowych wyjaśnień, odwołujących się czy to do retoryki, czy do szczególnego daru od Boga. Zwróćmy na przykład uwagę na tak zwane przemawianie ,z mocą”, znane nie tylko w Biblii, lecz obecne także dziś w środowiskach zielonoświątkowych. Słowo wydaje się mieć taką zdolność czy moc przekonywania, że wewnętrzne opory zagadniętego ustają. Pytanie tylko, czy jest to w konkretnej sytuacji wyzwolenie czy zniewolenie zagadniętego? Oczywiście, trzeba przy tym uwzględnić fakt, że u Ebnera wyzwolenie przychodzi przez słowo, słowo (jako „słowo właściwe”) wyzwala, inaczej mówiąc: duch „wdziera się" z zewnątrz i wyzwala człowieka z jego zamkniętości, „samotności Ja”. Zauważmy, że dla zaistnienia dialogu konieczne jest, by człowiek dał odpowiedź pochodzącą z domeny jego wolności. Być może jednak trzeba przemyśleć definicję wolności, na co nie ma tu miejsca, zasugerujmy więc tylko, że jeśli chcemy wolność rozumieć nie tyle jako brak ograniczeń, lecz jako „bycie u siebie”, to być może jego duch i jego wolność realizuje się właśnie w jego „byciu w relacji”, a nie w zamkniętości.

${ }^{11}$ Ferdinand Ebner, „Versuch eines Ausblicks in die Zukunft“, w: Ferdinand Ebner, Schriften, wyd. Franz Seyr, t. 1 (München: Kösel, 1963), 742.

12 Ferdinand Ebner, „Die Christusfrage“, w: Ferdinand Ebner, Schriften, wyd. Franz Seyr, t. 1 (München: Kösel, 1963), 469. 


\section{Duch a „zlamanie" życia biologicznego}

Zwróćmy uwagę, że duch według Ebnera rodzi się, czy może budzi się, często dopiero w sytuacji ,zlamania życia biologicznego". Nie ma tu miejsca na badanie, czy duch jest reakcją na owo „złamanie”, czy raczej jego przyczyną, podajmy jednak krótkie wyjaśnienie tego terminu: na poziomie biologicznym człowiek próbuje przede wszystkim ,potwierdzić się” na tym świecie, budując moc swoją czy swojej grupy przeciw innym. Dopiero gdy ta droga wyczerpie swoje możliwości i okaże się ślepą uliczką, człowiek staje się egzystencjalnie świadomy życia duchowego. Mówiąc lapidarnie, czy wręcz banalizując: gdy nie umiem pokonać drugiego, muszę się z nim dogadać. (Już w Ewangelii zauważyć można taki sposób myślenia: „który król, wyruszając na wojnę z drugim królem, nie usiądzie najpierw i nie naradzi się, czy będzie $\mathrm{w}$ stanie $\mathrm{w}$ dziesięć tysięcy zmierzyć się $\mathrm{z}$ tym, który z dwudziestoma tysiącami wyrusza przeciwko niemu? Jeśli zaś nie, to gdy tamten jeszcze jest daleko, wysyła poselstwo i zapytuje o warunki pokoju" [Łk 14, 31-32]). Tak więc rodzi się w tym kontekście pytanie, czy można temu złamaniu jakoś ,ppomóc” i jeśli tak, to jak, by było to wyzwolenie, a nie zniewolenie? Poruszamy się tu oczywiście po trudnej górskiej ścieżce, z której łatwo spaść w przepaść gloryfikacji przemocy. Inaczej mówiąc, grozi nam postawa „zmuszania” do ,dialogu, ale na moich warunkach”, a więc do czegoś, co de facto dialogiem już nie jest.

Warto jednak podkreślić, że jak to przekonująco opisuje Piotr Kostyło, podejście dialogiczne przybiera na sile wobec załamania dotychczasowych gwarantów pewności i bezpieczeństwa, co widać w przypadku samego Ebnera i rozkładu Austro-Węgier w czasie pierwszej wojny światowej i po niej ${ }^{13}$.

Jaką strategię wybrać więc, by skłonić drugiego do dialogu, zakładając oczywiście nastawienie dialogiczne u siebie samego? Jako przykład - chociaż na poziomie bardziej państw niż osób, a więc mutatis mutandis i z dużą dozą nieufności wobec transpozycji zachowań osoby na państwo - można by przytoczyć wypowiedzi dwóch wybitnych fizyków, a zarazem polityków: Edwarda Tellera (twórcy bomby wodorowej i doradcy prezydentów USA między innymi w sprawie ,gwiezdnych wojen”) i Hansa Petera Dürra (odkrycia z dziedziny fizyki kwantowej, główny współpracownik Heisenberga i działacz ruchów pokojowych, między innymi jeden z szefów Greenpeace).

13 Por. Piotr Kostyło, „Ferdinand Ebner i paradoks samotności”, Paedagogia Christiana 1 (2015): 79-98. 
Obaj nie tylko się znali (Dürr doktoryzował się u Tellera w USA), ale cenili się i mimo różnicy nastawień dyskutowali między sobą. Dürr opisuje te dyskusje w swoich książkach i wywiadach ${ }^{14}$ : Teller uważał, że potrzebne jest uzyskanie nad przeciwnikiem takiej przewagi - finansowej, militarnej itd., że zostanie zmuszony do podjęcia dialogu. Dürr uważał, że taka droga jest zła, a przynajmniej zbyt niebezpieczna. On sam podkreślał ważność rozmów z Gorbaczowem. Gdy miała miejsce pierestrojka, każdy z nich starał się podkreślić swoje zasługi w doprowadzeniu do niej. Czy zmiana nastawienia ZSRR była spowodowana międzyosobowym spotkaniem i przekonaniem Gorbaczowa, czy może raczej beznadziejną sytuacją ZSRR, który nie wytrzymał finansowo wyścigu zbrojeń? Kto był naiwny, a kto doprowadził do zakończenia zimnej wojny? Każdy z obu fizyków ma swoje argumenty, ale jednoznacznie do dziś nie rozstrzygnięto tego sporu.

Sam Ebner wydaje się odrzucać w swych pismach, przynajmniej tych z wczesnych lat dwudziestych, możliwość przemocy.

Wyrwijmy się wreszcie z zaklęcia tej prawdziwie nieszczęśliwej myśli, by złu i złemu odpowiadać w tym życiu nie inaczej niż przemocą. Dopóki uważamy, że musimy stosować przemoc, nie poradzimy sobie bez niej. Dopóki jesteśmy przekonani o nieuniknioności wojen... będą one miały miejsce, dopóki są sędziowie i prokuratorzy - będą też przestępcy... ${ }^{15}$

Dialogiczność jest nie do pogodzenia ze stosowaniem przemocy, nieodłącznego środka „tego świata”, działającego miękko czy twardo, zagrażającego ciału lub zniewalającego intelekt ${ }^{16}$. Nastawienie to naraża się jednak na zarzut ignorowania realiów życia społecznego i w ogóle cielesnego oraz zamykania się we wzajemności dialogu „dwóch dusz”. Wydaje się więc, że odpowiedniość środków prowadzących do dialogu daje się ocenić dopiero w konkretnej sytuacji, tak jak dialog sam w sobie nie jest zjawiskiem „ogólnym” czy „społecznym”, lecz wydarza się zawsze w konkretnej sytuacji między konkretnym Ja i Ty.

${ }^{14}$ Por. Hans-Peter Dürr, „Prof. Dr. Hans-Peter Dürr Physiker im Gespräch mit Reinhold Gruber", http://www.br.de/fernsehen/ard-alpha/sendungen/alpha-forum/hans-peter-duerr-gespraech100.html [dostęp: 29.12.2017].

15 Ferdinand Ebner, „Die Wirklichkeit Christi”, w: Ferdinand Ebner, Schriften, wyd. Franz Seyr, t. 1 (München: Kösel, 1963), 566.

16 Tamże, 547. 


\section{Przejrzystość kultury i wolność od ideologii}

Okoliczność, że wypowiadane słowo brzmi tak, a nie inaczej, że to czy owo oznacza, że jego adresat może je zrozumieć i zinterpretować, jest faktem języka, a więc faktem kultury. Pierwotne ,zanurzenie w kulturze” wyraża fakt, że - by użyć sformułowania Martina Heideggera - człowiek jest „rzucony”. Inaczej mówiąc, nie zaczyna od jakiegoś „punktu zero”, lecz zanim zacznie mówić, jest w jakiejś kulturze, w grupie z jej ideologią, w religii (przynajmniej jako organizacji, do której przynależy), w relacji itd. Ważne więc, jaka jest ta kultura w odniesieniu do dialogiczności. Ebner postuluje w swych późnych pismach, by na przykład sztuka czy w ogóle kultura były przejrzyste dla ducha ${ }^{17}$. Uzasadnione jest więc $\mathrm{w}$ tym kontekście pytanie, czy dane dzieło sztuki (przez które definiuje się dana kultura), dana organizacja, dane zachowanie prowadzi do dialogu, czy nie; zamyka czy otwiera na realność duchową - a więc na Ty? A może wyprowadza ono na manowce w świat ,snu o duchu”, prowadzi gdzieś daleko od - jak pisałem powyżej aktualności rzeczowej? Należy wtedy zapytać, czy to jeszcze kultura, czy już pogardzająca jednostką ideologia.

Udziałem człowieka jest bowiem nie tylko kultura, ale również ideologia, tu w sensie nieadekwatnego, ale budującego grupę ujęcia rzeczywistości: niektórzy myśliciele negują wręcz istnienie Ja jako czegoś innego niż subiektu - nośnika ideologii. Przykładowo, wywodzący swoje myślenie z neomarksistowskich kręgów Louis Althusser prezentuje w znanej rozprawie Ideologie i aparaty ideologiczne państwa ${ }^{18}$ sytuację, gdy słowo ideologiczne (z Ebnerowskiego punktu widzenia: byłoby to „słowo bez miłości”) czyni z człowieka subiekt (fr. sujet) ideologii.

Sugerujemy przeto, że ideologia „działa” lub „funkcjonuje” w ten sposób, że „rekrutuje” podmioty [,subiekty” - K. S.] spośród jednostek (rekrutuje je

17 Por. Ebner, Schriften, t. 2, 1032. Ebner mówi tu o ,przejrzystości farby” malarza, która stoi w związku z tym, że jego życie ,staje się coraz bardziej przejrzyste w świetle prawdy z Wysoka”.

18 Por. Louis Althusser, „Ideologie i aparaty ideologiczne państwa”, www.filozofia. uw.edu.pl/skfm/publikacje/althusser05.pdf [dostęp: 20.03.2018]. W cytowanym thumaczeniu skorygowałbym ,podmiot” na ,subiekt”, by podkreślić fakt, że człowiek zostaje w ten sposób „poddany” ideologii oraz klasie społecznej, którą owa ideologia reprezentuje. 
wszystkie), albo „przekształca” jednostki w podmioty [,subiekty”] (przekształca wszystkie), poprzez tę ścisłą operację, którą nazwaliśmy interpelacją, a którą można sobie wyobrazić na wzór najbanalniejszego wezwania policyjnego (albo nie) wszystkich czasów: „Hej, ty tam!”19.

Można by powiedzieć, że tutaj słowo „Ty”, zagadnięcie, nie wyzwala, lecz zniewala, a dzieje się tak, bo człowiek nie zostaje zagadnięty przez „Ja”, lecz przez „subiekt ideologii”. Człowiek nie ma więc „swojego Ja”, ma co najwyżej „Ja ideologii”, mówi więc tylko w imieniu ideologii (być może co najwyżej grupy, a więc pewnego „my”), którą w sobie nosi czy z jaką się utożsamia. Także w innym nie widzi on „Ty”, lecz subiekt tej samej lub wrogiej ideologii. Aby dojść do dialogu, trzeba wyjść z takiego - właśnie „nieprzejrzystego" na ducha - widzenia człowieka, w którym duch przestaje być widoczny. Tak więc droga do dialogu to także przezwyciężanie ideologii.

\section{Słowo bez miłości}

Ideologia jest przykładem słowa bez milości. W oparciu o przykład z Althussera, ale także w doświadczeniu codziennym, można sobie przedstawić sytuację, gdy jak najbardziej poszukiwane jest Ty, lecz jedynie w celu podporządkowania go sobie, lub wręcz zniszczenia go. Taka sytuacja ma w sobie zaiste coś diabolicznego - stąd Tischner słusznie mówi w tym kontekście o złu. Słowo bez miłości jest słowem „zdeprawowanym”, oderwanym od swego pierwotnego celu.

Wobec „słowa właściwego”, powiązanego ze swym źródłem (mówiący jest przecież zawsze już ,zagadnięty” z zewnątrz, ostatecznie - jak podkreśla Ebner - przez Boga), które nie jest nigdy narzędziem zniszczenia drugiego takie „słowo bez miłości” nie ma racji bytu. Na płaszczyźnie ducha przeciwnikiem nie jest nigdy Drugi, lecz jest nim zło, a celem jest dialog... Inaczej może się okazać, że walczę przeciw komuś i udaje mi się go zniszczyć, a potem okazuje się, że jednak przegrałem, bo grałem po prostu w niewłaściwą grę. By wziąć jako przykład piłkę nożną: nie polega ona na faulowaniu przeciwnika, lecz na strzelaniu goli, nawet gdy w ferworze walki temu czy innemu brutalowi zatrze się jej cel.

19 Tamże. 


\section{Waga i powaga słowa}

To, co stwierdziłem do tej pory, można by podsumować jako podkreślenie wagi oraz powagi słowa. Słowo wypowiadane jako nie ponadczasowe, lecz aktualne, to jest umiejscowione w czasie, pozostaje więc związane z wypowiadającym je Ja i przyjmującym je Ty oraz z całym kontekstem. Słowo takie, w odróżnieniu od idei, nie daje się „wycofać” (dodajmy, że Ebner mówi o „wycofaniu idei” - Zurücknahme der Idee) ${ }^{20}$, tak że dokonuje się powrót do stanu przed jego wypowiedzeniem - $\mathrm{i}$ to jest jego powaga. Tylko takie słowo jest owym ,słowem właściwym”, posiadającym moc ,generatywną", mogącym przemienić, wyzwolić, wprowadzić w dialog. Chodzi więc o trwanie przy tak rozumianej ,powadze" słowa, nawet gdy cena za to jest wysoka.

Wrócę jeszcze raz do przykładu z książki Watzlawicka: kiedy nie widzę gotowego do dialogu Ty, to nie udaję, że je widzę. W myśl formuły Watzlawicka „nie mogę się nie komunikować” ${ }^{21}$, komunikacja mimo otwartej odmowy czy uniku trwa dalej - ale nie każda komunikacja jest dialogiem. Chcąc dialogu, nie godzę się na fałszywe Ty. Nie godzę się też na paplaninę - fałszywe czy puste słowo. Jedynym prawdziwie dialogicznym nastawieniem jest, by starać się zbudować podstawy do dialogu, czy to usiłując wykorzystać moc swego słowa, by obudzić Ty w innym, czy to odmawiając wypowiedzi (komunikując jednak przez to, że nie ma warunków do dialogu), czy ostatecznie próbując ratować moje Ja przed wykorzystaniem czy wręcz zniszczeniem. Nie przyjmuję żadnej optyki, która zniekształca aktualną rzeczywistość - ani tej po prostu fałszywej, ani tej idealistycznej (ogólnej). Prawdziwie dramatyczną walkę o dialog dostrzec można w Ewangeliach: prezentuje ją Jezus przed swymi oskarżycielami: przywódcami żydowskimi i Piłatem. Nie pozwala on używać swego słowa do „niedialogicznych” celów - kpin czy oskarżeń. Czasami wypowiada słowa odnoszące się do osobistej sytuacji interlokutorów: „dlaczego mnie bijesz?” „Nie miałbyś nade mną władzy, gdyby ci jej nie dano z góry" - poza tym milczy. Taka dramatyczna walka o dialog, takie trzymanie się słowa w jego aktualności, zarówno rzeczowej, jak i osobistej: „,przyszedłem na świat, by dać świadectwo prawdzie", może prowadzić na krzyż.

\footnotetext{
${ }^{20}$ Ebner, Stowo, 41, 115.

${ }^{21}$ Watzlawick, Bavelas, Jackson, Pragmatics, 53.
} 


\section{Heroizm i tragedia}

Sugeruje to oczywiście, że dialog nie zawsze musi się udać, że dramat nie zawsze kończy się happy endem. Ebner mówi tu raczej teologicznie o „zgubie” bądź „zbawieniu”. Wróćmy w tym momencie do Tischnera, który stosuje w tym kontekście takie określenia, jak „heroizm” i „tragedia” jako możliwe zakończenia dramatu: „Dramat otwiera możliwość heroizmu, otwiera też możliwość tragedii, która polega na zwycięstwie zła nad dobrem. Heroiczny tryumf dobra nad złem może być tryumfem mocy odsłaniającej niezniszczalność dobra lub tryumfem prawdy przebijającej się przez wszelkie iluzje"22. Natomiast „tragedia kończy się wydarzeniem, w którym dobro ukazuje swą bezsiłę w sporze ze złem" "23. Pojawia się tutaj przeciwstawienie: tragiczność (niedialogiczność całkowita czy też doświadczanie jej śladów w relacji z innym) kontra heroiczność (trwanie w postawie dialogu mimo zagrożenia nawet samego życia biologicznego).

O tragiczności Tischner mówił także jako, że tak powiem, o „negatywnej stronie” dialogu. Miał przy tym na myśli coś analogicznego do „negatywności” u Hegla, „z tym jednak zastrzeżeniem, że w miejsce Heglowskiej negatywności wprowadza pojęcie tragiczności"24. Ta zaś negatywność jest podstawą rozwoju i drogi do prawdy: „duch odnajduje swą prawdę tylko wtedy, gdy negatywności patrzy prosto w oczy i przy niej się zatrzymuje"25. To stwierdzenie przypomina, że o dialog walczyć trzeba ciągle, nie można zaprzestać tej walki po jednorazowym sukcesie. Myśliciele dialogiczni, w tym Ebner, mówią też o odczuwanej odnośnie do drugiego obcości (Tischner widzi ją jako przejaw „zła”) i ciągłym jej przezwyciężaniu.

Działa to jednak także „w drugą stronę”, to znaczy, że raz doznana „tragedia" nie musi trwać na zawsze, dopóki trwa Ja. Pozostaje nadzieja. Dlatego też nie można potępiać opisywanej przez Watzlawicka „ucieczki” w sen czy - gdy nie jest to możliwe - w schizofrenię. Chodzi przecież o to, by zachować Ja „na lepsze czasy”.

${ }^{22}$ Tadeusz Gadacz, „Problem zła w filozofii Józefa Tischnera”, http://www.tischner.org. pl/tadeusz-gadacz/problem_zla_w_filozofii_jozefa_tischnera [dostęp: 15.03.2018].

23 Józef Tischner, Filozofia dramatu (Kraków: Znak, 1998), 64.

${ }^{24}$ Gadacz, „Problem”.

25 Tamże. 


\section{$* * *$}

W kontekście dochodzenia do dialogu nie można oczekiwać determinizmu w sensie: „gdy zrobię to a to, to rozpocznie się dialog”. Takie myślenie pozostawałoby na poziomie idei, a więc ,samotności Ja” i nie uwzględniałoby podmiotowości Drugiego - partnera dialogu. Co więcej, takie myślenie zamykałoby właśnie drogę do dialogu. Zawsze wchodzi tu w grę jakiś element wolności - czy też, w sensie negatywnym, samowoli. Nieprzypadkowo zarówno Tischner, jak i Ebner mówią w tym kontekście o łasce. Napisałem powyżej, że dopóki trwa Ja, pozostaje nadzieja. Takie stwierdzenie jest szczególnie pozytywne z punktu widzenia chrześcijaństwa: Ja jest realnością duchową, gdy pozostaje w dialogu, a pozostaje ono w dialogu z Ty boskim, nawet gdy akurat w konkretnym człowieku owo Ty nie może znaleźć swego wyrazu. Tak więc nawet gdy nie uda mi się skłonić drugiego człowieka do dialogu, to jeśli prowadzę dialog z Bogiem, już triumfuję. Dlatego też dialog, dialogiczne nastawienie, wiąże się przynajmniej z otwartością na Boga, na wiarę, na to że także $\mathrm{z}$ tej strony mogę zostać zagadnięty, a nawet już zostałem zagadnięty i „ktoś” oczekuje odpowiedzi.

\section{Through Drama to Dialogue. The Role of "Word" in the Arriving at Dialogue according to Ferdinand Ebner (Summary)}

Dialogue philosophers who are realistic about their matter, pay more attention to the arriving at dialogue than to dialogue itself. We see such an attitude, among others, in the writings of Ferdinand Ebner and Józef Tischner. Dialogue is a target situation, while the road to it is long and uncertain - according to Tischner, it leads through drama. Ebner, on whom we focus here in particular, sees the matter as follows: The "I" communicate with "You" through word and love. If the dialogue fails, then one of these four elements simply lacks. Because of the lack of space for the analysis of all these elements, we will focus on the word here. So what must the word be for dialogue to be possible? Let us list such characteristics of the word as its "actuality", both factual and personal, transparency in relation to the presented reality, connection with love, creative power (generative or "only" maieutic) and much more. However, it is difficult to deterministically define the terms of dialogue saying: When I do this and this, dialogue will definitely succeed. There is always an element of freedom and grace, as well as hope. 
Keywords: Ferdinand Ebner; conditions of dialogue; philosophy of dialogue; philosophy of a drama; word.

\section{Przez dramat do dialogu. Rola „Słowa” w dochodzeniu do dialogu według Ferdynanda Ebnera (Streszczenie)}

Filozofowie dialogu realistycznie podchodzący do sprawy więcej uwagi poświęcają dochodzeniu do dialogu niż samemu dialogowi. Postawę taką dostrzegamy między innymi w pismach Ferdynanda Ebnera i Józefa Tischnera. Dialog jest sytuacją docelową, natomiast droga do niego jest długa i niepewna - według Tischnera wiedzie przez dramat. Ebner zaś, na którego myśli skupiamy się szczególnie, widzi sprawę następująco: Ja komunikuje się z Ty poprzez słowo oraz miłość. Jeśli dia$\log$ się nie udaje, to któregoś z tych elementów po prostu brakuje. $Z$ braku miejsca na analizę wszystkich czterech elementów, skupimy się na słowie. Jakie musi być więc słowo, by dialog był możliwy? Wymieńmy takie cechy słowa jak choćby jego aktualność (zarówno rzeczowa, jak i osobowa), przejrzystość względem przedstawianej rzeczywistości, połączenie z miłością, moc sprawcza o charakterze generatywnym lub „tylko” maieutycznym. Trudno jednak deterministycznie określić warunki dialogu na zasadzie: gdy zrobię to i to, dialog na pewno się uda. Zawsze pozostaje bowiem element wolności i łaski, a także nadziei.

Slowa kluczowe: Ferdynand Ebner; warunki dialogu; filozofia dramatu; filozofia dialogu; słowo.

\section{Bibliografia}

Althusser, Louis. „Ideologie i aparaty ideologiczne państwa”. www.filozofia.uw.edu. pl/skfm/publikacje/althusser05.pdf [dostęp: 20.03.2018].

Dürr, Hans-Peter. „Prof. Dr. Hans-Peter Dürr Physiker im Gespräch mit Reinhold Gruber". http://www.br.de/fernsehen/ard-alpha/sendungen/alpha-forum/hans-peter-duerr-gespraech100.html [dostęp: 29.12.2017].

Ebner, Ferdinand. „Die Christusfrage“. W: Ferdinand Ebner, Schriften, wyd. Franz Seyr, t. 1, 450-505. München: Kösel, 1963.

Ebner, Ferdinand. „Die Wirklichkeit Christi”. W: Ferdinand Ebner, Schriften, wyd. Franz Seyr, t. 1, 522-573. München: Kösel, 1963. 
Ebner, Ferdinand. „Versuch eines Ausblicks in die Zukunft“. W: Ferdinand Ebner, Schriften, wyd. Franz Seyr, t. 1, 719-908. München: Kösel, 1963.

Ebner, Ferdinand. Schriften, wyd. Franz Seyr, t. 2. München: Kösel, 1963.

Ebner, Ferdynand. Słowo i realności duchowe. Fragmenty pneumatologiczne, thum. Krzysztof Skorulski. Chojnice: Oficyna Wydawnicza Fundacji Fuhrmanna, 2016.

Gadacz, Tadeusz. „Problem zła w filozofii Józefa Tischnera”. http://www.tischner. org.pl/tadeusz-gadacz/problem_zla_w_filozofii_jozefa_tischnera [dostęp:15.03. 2018].

Kostyło, Piotr. „Ferdinand Ebner i paradoks samotności”. Paedagogia Christiana 1 (2015): 79-98.

Methlagl, Walter. „Konflikt aspektów. Ferdinanda Ebnera myślenie w odniesieniach". Paedagogia Christiana 1 (2015): 41-62.

Skorulski, Krzysztof. „Ferdinand Ebner i miejsce filozofii dialogu w myśli katolickiej XX wieku". Paedagogia Christiana 1 (2011): 49-68.

Tischner, Józef. Filozofia dramatu. Kraków: Znak, 1998.

Tischner, Józef. Spór o istnienie człowieka. Kraków: Znak, 1999.

Watzlawick, Paul, Janet Beavin Bavelas, Don D. Jackson. Pragmatics of Human Communication: A Study of Interactional Patterns, Pathologies, and Paradoxes. New York: Norton, 1967. 
